\title{
THE DOUBTFUL NATURE OF "LUXUSKONSUMPTION" 1
}

\author{
By F. H. WILEY ${ }^{2}$ AND L. H. NEWBURGH
}

(From the Department of Internal Medicine, Medical School, University of Michigan, Ann Arbor)

(Received for publication May 22, 1931)

In 1911, and several times thereafter, Grafe and his associates (1) stated that the fasting, resting metabolism of an individual is not proportional to the surface area, but is significantly affected by the calorific value of the food previously ingested. They also postulated that the total metabolism is influenced in the same way by the total intake of energy. According to them, normal animals, including man, maintain a constant weight, almost without regard to the energy intake, and obesity is often nothing more than the failure of this alleged mechanism to respond normally to the stimulus of food. Finally, leanness is an over-response to a normal stimulus.

They supported these views by the following type of experiments: A dog was starved for a long time, and its resting, fasting metabolism was then determined. This value was used as the basis for comparison. The dog was now offered an abundance of food, and gained weight rapidly. The metabolism was repeatedly determined in the fasting, resting state. The metabolic rate thus determined showed a progressive increase out of proportion to the increase in body surface. Table I sets forth their data in detail, rearranged by us.

This increase in metabolic rate of the overfed animal beyond that of the starved animal was accepted by them as proof that the resting, fasting metabolism of the normal animal is increased by previous overfeeding. But the metabolic rate obtained after prolonged starvation should not have been accepted as a proper basis for comparison, since Schöndorff (2) had previously shown that starvation caused a decrease

1 The expenses of this investigation were defrayed in part by a fund for the study of nutrition, created by Mr. W. K. Kellogg, of the Kellogg Corn Flake Company, Battle Creek, Michigan.

${ }^{2}$ National Research Council Fellow in Medicine. 
TABLE I

Effect of different degrees of nutrition upon basal metabolism, according to Grafe

\begin{tabular}{|c|c|c|c|c|c|}
\hline \multirow{2}{*}{ Diet and length of period } & \multirow{2}{*}{ Body weight } & \multicolumn{2}{|c|}{$\begin{array}{l}\text { Basal heat production } \\
\text { per } 24 \text { hours }\end{array}$} & \multicolumn{2}{|c|}{ Basal metabolic rate } \\
\hline & & Determined & Predicted * & After Gräfe & Standard \\
\hline Beginning & $\begin{array}{l}\text { kgm. } \\
20.15\end{array}$ & $\begin{array}{c}\text { Calories } \\
1056\end{array}$ & $\begin{array}{c}\text { Calories } \\
987\end{array}$ & $\begin{array}{c}\text { per cent } \\
+54\end{array}$ & $\begin{array}{c}\text { per cent } \\
+7\end{array}$ \\
\hline $\begin{array}{l}21 \text { days } \\
\text { Starvation } \\
21 \text { st day }\end{array}$ & 15.00 & 672 & 905 & \pm 0 & -26 \\
\hline $\begin{array}{l}7 \text { days } \\
2243 \text { Calories per day } \\
4 \text { th day }\end{array}$ & 18.50 & 816 & 963 & +19 & -15 \\
\hline $\begin{array}{l}29 \text { days } \\
2580 \text { Calories per day } \\
29 \text { th day }\end{array}$ & 20.25 & 1047 & 992 & +53 & +5 \\
\hline $\begin{array}{l}11 \text { days } \\
1659 \text { Calories per day } \\
11 \text { th day }\end{array}$ & 20.17 & 1112 & 989 & +62 & +11 \\
\hline $\begin{array}{l}19 \text { days } \\
1120 \text { Calories per day } \\
19 \text { th day }\end{array}$ & 20.00 & 1061 & 980 & +55 & +8 \\
\hline $\begin{array}{l}10 \text { days } \\
882 \text { Calories per day } \\
10 \text { th day }\end{array}$ & 18.50 & 839 & 963 & +22 & -13 \\
\hline $\begin{array}{l}7 \text { days } \\
\text { Starvation } \\
6 \text { th day }\end{array}$ & 17.50 & 856 & 946 & +25 & -9 \\
\hline 2 months Unrestricted & 21.00 & 1005 & 1005 & +48 & \pm 0 \\
\hline
\end{tabular}

* Predicted heat production was obtained from heat production determined after the animal had led an unrestricted life for two months. This value was corrected for changes in surface area as indicated by change in weight from $21.00 \mathrm{kgm}$. 
in this rate. Zuntz (3) later showed that this decrease might be as much as 30 per cent below the normal. In spite of the demonstration by Schöndorff, that a starved dog has a greatly depressed rate, Gräfe accepted the heat production of his dog, after 21 days' starvation, as a proper value for the basis of his calculations. The 24 hourly heat production of 672 Calories was thus erroneously used as the norm with which to compare the metabolism of overnutrition. When the animal was normal, in the usual sense of the word (i.e. after 2 months of food ad libitum), its heat production was 1,005 Calories. Starvation had accordingly reduced it 26 per cent. Liberal feeding permitted the basal metabolism to return to approximately the normal value, which at its height was 62 per cent above the starvation level but only 11 per.cent more than the normal value.

In 1912, Grafe and Koch (4) reported the study of a man whose normal weight was $62.62 \mathrm{kgm}$. and whose height was $156.2 \mathrm{~cm}$. He was 35 years old. He came to the hospital suffering from stenosis of the pylorus accompanied by persistent vomiting. His weight had fallen to $40 \mathrm{kgm}$. His fasting, resting metabolism was determined, the stenosis was then relieved by operation, and ten days later a period of overnutrition was begun. It lasted seven weeks, at the end of which time the patient's weight had again become $60 \mathrm{kgm}$.

Inspection of Table II makes it clear that the undernourished patient

TABLE II

Effect of different degrees of nutrition upon basal metabolism, according to Grafe Sex-M. Height-156.5 cm. Age-35 years

\begin{tabular}{c|c|c|c|c|c}
\hline \hline Condition of patient & Weight & Surface area & $\begin{array}{c}\text { Calories per square } \\
\text { meter per hour }\end{array}$ & $\begin{array}{c}\text { Basal meta- } \\
\text { bolic rate }\end{array}$ \\
\hline & $\begin{array}{c}k g m . \\
40.0\end{array}$ & $\begin{array}{c}\text { square meters } \\
1.34\end{array}$ & 30.5 & 39.0 & $\begin{array}{c}\text { per cent } \\
-22\end{array}$ \\
\cline { 2 - 5 } Before operation & 40.0 & 1.34 & 29.5 & 39.0 & -24 \\
\hline $\begin{array}{c}\text { After operation and } \\
\text { period of overnutrition. } \\
\text { (100 Calories per kilo) }\end{array}$ & 60.2 & 1.59 & 40.1 & 39.0 & +2 \\
\hline
\end{tabular}


exhibited the usual depression of the metabolic rate. When the operation had made it possible for him to absorb food in large quantities, the ingestion of 100 Calories per kilogram caused him to gain in the neighborhood of $22 \mathrm{kgm}$. in less than two months, and in addition merely permitted the oxidative rate to return to the normal level. There is, then, no evidence that "Luxuskonsumption" increased the fasting, resting metabolism.

It should be recalled that Grafe had said that the normal animal maintained a constant weight in spite of overfeeding, because the extra food stimulated the total metabolism to such an extent that the excess was oxidized, but he published no data that dealt with the total metabolism.

We have, accordingly, reinvestigated this question. In a recent publication from this laboratory (5), we have shown that quantitative data regarding the total metabolism may now be secured, and such data are included in our study.

The subject was a very thin young man, who weighed $57.5 \mathrm{kgm}$. (nude), and whose height was $180 \mathrm{~cm}$. (6 feet). He was 28 years old at the time the experiment was undertaken. At the age of 17 he had attained his full height and weighed only $50 \mathrm{kgm}$. (110 lbs.). By the time he was 20 years old he had attained his present weight. During his twenty-first year, for a period of 3 months, he happened to be eating food that tasted unusually good. He was fully aware of eating much more food than usual, and feeling unusually indolent. During these 3 months his weight increased about $11 \mathrm{kgm}$. (25 lbs.). Following this unusual experience, he again partook of food which made no unusual appeal to him. In spite of his unusual height and leanness, he was quickly satiated and did not indulge in the common custom of eating before retiring. He failed to derive the usual pleasure from sweets and pastries. His mother diligently tried, without success, to get him to eat what she considered a sufficient amount. She even forced him to take a variety of "tonics" with the hope of increasing his weight. Hence on the basis of his food habits, his leanness might as easily be attributed to an unusually small intake of energy as to an abnormally great oxidative rate.

On November 5, 1930, he began to eat all of his food in the hospital diet kitchen. His dietetic prescription was protein 91 grams, fat 186 
grams, and carbohydrate 241 grams, giving about 3,000 Calories. To avoid monotony the dietitian fed these materials in the form of different foodstuffs for three consecutive days, and used precisely the same foodstuffs for every subsequent three day period. The occupation of the subject was that of a professional chemist, and he made no conscious alteration in the routine of his life. On November 23, 1930, the diet prescription was changed to protein 89 grams, fat 413 grams, and carbohydrate 445 grams, giving about 5,000 Calories. The food was fed according to the above described plan. During part of the second period his activity was slightly, but definitely, increased due to pressure of extra work. This second diet was continued through December 7, 1930. Thereafter, until January 5, 1931, he made a serious effort to continue to gain weight by overeating. From the latter date until March 19 he took food according to his desires.

Sample diets of each period covering the three day cycle, and intended to be identical with those served to the subject, were prepared by the dietitian except that the milk, cream, butter and sugar were mitted. The milk, cream and butter are regularly analyzed by thes ohospital chemist, and are found to conform with standard value. The sample diets were dried over a steam bath, weighed and ground to a fine powder. A thoroughly mixed sample was then ignited in a bomb calorimeter to obtain its heat value. In addition, the nitrogen, fat and ash content were determined.

The nude, fasting weight of the subject was recorded every third morning. The total weight of the ingesta, and of urine and stool, was also obtained for each three day period. The urine and stools were analyzed for nitrogen and total solids, and the heat value of the dried stool was obtained by means of the bomb calorimeter. The basal metabolism was measured three times during the first period, five times during the second period, and several times thereafter.

The actual total energy of the diet for the eighteen day period was obtained as follows: the milk, cream, butter and sugar were found to contain, by calculation, 33,246 Calories. The energy value of the remainder of the diet, as determined by means of the calorimeter, was 23,436 Calories, giving a total of 56,682 Calories. The dried stool contained 2,450 Calories, and the urine contained 1,644 Calories (urinary nitrogen $\times 8$ ). The subtraction of the energy lost by excretion from 
the total potential energy of the diet left 52,588 Calories available to the organism.

The weights of the subject, ingesta, stool and urine, contained in Table III, permit the calculation of the insensible loss of weight. By

TABLE III

Data from our subject on maintenance diet

Diet-3,000 Calories

\begin{tabular}{|c|c|c|c|c|c|c|c|c|c|}
\hline \multirow{2}{*}{ Date } & \multirow{2}{*}{$\begin{array}{c}\text { Body } \\
\text { weight } \\
\text { at be- } \\
\text { ginning } \\
\text { of period }\end{array}$} & \multirow{2}{*}{$\begin{array}{l}\text { Weight } \\
\text { of } \\
\text { ingesta }\end{array}$} & \multirow{2}{*}{$\begin{array}{c}\text { Weight } \\
\text { of urine } \\
\text { and stool }\end{array}$} & \multirow{2}{*}{$\begin{array}{l}\text { Insen- } \\
\text { sible } \\
\text { loss of } \\
\text { weight }\end{array}$} & \multirow{2}{*}{$\begin{array}{c}\text { Surface } \\
\text { area }\end{array}$} & \multicolumn{2}{|c|}{ Basal metabolism } & \multirow{2}{*}{$\begin{array}{l}\text { Basal } \\
\text { meta- } \\
\text { bolic } \\
\text { rate }\end{array}$} & \multirow{2}{*}{$\begin{array}{l}\text { Respi- } \\
\text { ratory } \\
\text { quo- } \\
\text { tient }\end{array}$} \\
\hline & & & & & & $\begin{array}{c}\text { Pre- } \\
\text { dicted }\end{array}$ & $\begin{array}{l}\text { Deter- } \\
\text { mined }\end{array}$ & & \\
\hline & grams & grams & grams & grams & $\begin{array}{l}\text { square } \\
\text { meters }\end{array}$ & Calories & Calories & per cent & \\
\hline \multicolumn{10}{|l|}{$\begin{array}{c}\text { Novem- } \\
\text { ber } 1930\end{array}$} \\
\hline $5-6-7$ & 57,562 & 7,227 & 3,348 & 3,863 & 1.73 & 1,640 & 1,470 & -10.4 & .854 \\
\hline $8-9-10$ & 57,578 & 7,285 & 3,031 & 4,413 & & & & & \\
\hline $11-12-13$ & 57,439 & 6,894 & 2,853 & 3,537 & 1.73 & 1,640 & 1,510 & -8.0 & .811 \\
\hline $14-15-16$ & 57,943 & 7,466 & 3,750 & 3,801 & & & & & \\
\hline $17-18-19$ & 57,858 & 6,960 & 2,619 & 4,104 & 1.73 & 1,640 & 1,450 & -11.5 & .776 \\
\hline $20-21-22$ & 58,122 & 7,457 & 4,132 & 3,899 & & & & & \\
\hline \multirow[t]{2}{*}{23} & 57,548 & & & & & & & -10.0 & \\
\hline & & & & $\begin{array}{c}\text { Total } \\
23,617\end{array}$ & & & $\begin{array}{c}\text { Average } \\
1,475\end{array}$ & & \\
\hline
\end{tabular}

subtracting from the body weight at the end of the period the weight of the ingesta, and adding to this value the weights of the urine and stool, and subtracting this modified final weight from the initial weight, the insensible loss of weight was obtained (5). The total insensible loss for the eighteen days was 23,617 grams. In the earlier publication (5), we have shown that the total dissipation of heat may be calculated from the insensible water. Its weight in turn may be calculated by subtracting the difference between the weight of the exhaled carbon dioxide and that of the absorbed oxygen from the insensible loss of weight. A discussion of the method for determining these values may be found in the previous paper (5). In this instance they were 17,674 grams of carbon dioxide and 16,021 grams of oxygen, giving a difference of 1,653 grams. Thus the insensible water was 21,964 grams. The heat re- 
moved by it was obtained by multiplying it by 0.58 . This heat represents 24 per cent of the total heat dissipated (5). The heat dissipation calculated in this manner was 53,087 Calories for eighteen days, or 2,947 Calories per twenty-four hours. Accordingly, it is true that this subject, leading his usual life, transformed energy at the rate of 2,947 Calories per day when he was receiving 2,922 Calories per day.

Will he, then, transform more energy merely because he ingests more food?

The subject was, accordingly, fed the second diet, the calorific value of which was roughly 5,000 Calories per day, for 15 days. Accurate information was obtained for this period in the same manner as has been described for the first period. It was found that the total energy of the diet was 75,125 Calories for the period. The stools for the period contained 2,745 Calories, and the urine contained 1,056 Calories, giving a total of 71,324 Calories available to the organism.

TABLE IV

Data from same subject on supermaintenance diet

Diet-5,000 Calories

\begin{tabular}{|c|c|c|c|c|c|c|c|c|c|}
\hline \multirow{2}{*}{ Date } & \multirow{2}{*}{$\begin{array}{l}\text { Body } \\
\text { weight } \\
\text { at be- } \\
\text { ginning } \\
\text { of period }\end{array}$} & \multirow{2}{*}{$\begin{array}{c}\text { Weight } \\
\text { of } \\
\text { ingesta }\end{array}$} & \multirow{2}{*}{$\begin{array}{c}\text { Weight } \\
\text { of urine } \\
\text { and stool }\end{array}$} & \multirow{2}{*}{$\begin{array}{l}\text { Insen- } \\
\text { sible } \\
\text { loss of } \\
\text { weight }\end{array}$} & \multirow{2}{*}{$\begin{array}{c}\text { Surface } \\
\text { area }\end{array}$} & \multicolumn{2}{|c|}{ Basal metabolism } & \multirow{2}{*}{$\begin{array}{l}\text { Basal } \\
\text { meta- } \\
\text { bolic } \\
\text { rate }\end{array}$} & \multirow{2}{*}{$\begin{array}{c}\text { Respi- } \\
\text { ratory } \\
\text { quo- } \\
\text { tient }\end{array}$} \\
\hline & & & & & & $\begin{array}{c}\text { Pre- } \\
\text { dicted }\end{array}$ & $\begin{array}{l}\text { Deter- } \\
\text { mined }\end{array}$ & & \\
\hline & grams & grams & grams & grams & $\begin{array}{l}\text { square } \\
\text { meters }\end{array}$ & Calories & Calories & per cent & \\
\hline $\begin{array}{l}\text { Novem- } \\
\text { ber } 1930\end{array}$ & & & & & & & & & \\
\hline $23-24-25$ & 57,548 & 8,324 & 2,258 & 4,143 & & & & & \\
\hline $26-27-28$ & 59,471 & 8,218 & 3,463 & 4,227 & 1.76 & $1,65.1$ & 1,560 & -5.5 & .869 \\
\hline \multicolumn{10}{|l|}{ 29-30- } \\
\hline $\begin{array}{c}\text { Decem- } \\
\text { ber } 1\end{array}$ & & 7.991 & 3.189 & 4.369 & 177 & & 1545 & & 875 \\
\hline $\begin{array}{l}\text { ber } 1 \\
2-3-4\end{array}$ & $\begin{array}{l}59,999 \\
60,432\end{array}$ & $\begin{array}{l}7,991 \\
8,292\end{array}$ & $\begin{array}{l}3,189 \\
2,739\end{array}$ & $\begin{array}{l}4,369 \\
4,691\end{array}$ & $\begin{array}{l}1.77 \\
1.77\end{array}$ & $\begin{array}{l}1,000 \\
1,660\end{array}$ & $\begin{array}{l}1,543 \\
1,575\end{array}$ & $\begin{array}{l}-0.9 \\
-5.1\end{array}$ & $\begin{array}{l}.815 \\
.843\end{array}$ \\
\hline $5-6-7$ & 61,294 & 7,391 & 2,414 & 4,313 & 1.78 & 1,670 & 1,600 & -4.2 & .903 \\
\hline \multirow[t]{2}{*}{8} & 61,958 & & & & 1.79 & 1,679 & 1,610 & -4.1 & .880 \\
\hline & & & & $\begin{array}{r}\text { Total } \\
21,743\end{array}$ & & & & & \\
\hline
\end{tabular}

Table IV gives the weights of the subject, ingesta, stool and urine for the second period. The total insensible loss calculated from the 
table was 21,763 grams. The total nitrogen of the urine was 132 grams. The metabolic mixture was calculated from the carbohydrate of the diet, the nitrogen excretion and the insensible loss of weight by the method described in the earlier paper (5). It was found to consist of 871 grams of protein, 1,928 grams of fat, and 6,315 grams of carbohydrate for the period of fifteen days. The corresponding carbon dioxide and oxygen values were respectively 16,357 grams and 13,752 grams. The difference, 2,605; subtracted from the total insensible loss, 21,763, gave 19,158 grams of insensible water for the period. The total heat dissipation indicated by this value was 46,298 Calories for fifteen days, or 3,082 Calories per day. Accordingly, the subject transformed 135 more Calories of energy per day when he was ingesting about 5,000 Calories than when the intake of energy was about 3,000 Calories, an increase of about 4.5 per cent in total metabolism.

The average surface area for the second period was 2.3 per cent greater than for the first period. Other things being equal, this would call for an average increase of 67.5 Calories per day in the second period, leaving 68 Calories per day thus far unaccounted for. These 68 Calories may be properly attributed to the specific dynamic effect of the extra fat and carbohydrate of the diet in this period, since there is a quantitative relationship between the amount of material ingested and its dynamic effect. Lusk (6) has recently stated that the metabolism is increased after the ingestion of fat and carbohydrate by four per cent and six per cent respectively of the Calories furnished by these foodstuffs. In the second period the fat was 116 grams and the carbohydrate 180 grams greater per day than in the first period. Four per cent of the extra Calories in the fat is 42 , and six per cent of the extra Calories in carbohydrate is 43 . Thus the total metabolism should have increased in the second period 85 Calories, due solely to the extra food ingested. It will be recalled that the calculations required us to account for 68 Calories in this way. Thus all of the increase in the total metabolism is disposed of without recourse to "Luxuskonsumption."

From Tables III and IV it may be seen that the basal metabolic rate in the second period was about 5 per cent higher than in the first period.

An inspection of the respiratory quotients for each period shows that they were markedly higher when the subject was taking the excessive 
TABLE V

Return of subject to maintenance diet

\begin{tabular}{|c|c|c|c|c|c|c|c|}
\hline \multirow{2}{*}{ Date } & \multirow{2}{*}{ Diet } & \multirow{2}{*}{$\begin{array}{l}\text { Body } \\
\text { weight } \\
\text { at end } \\
\text { of period }\end{array}$} & \multirow{2}{*}{$\begin{array}{c}\text { Surface } \\
\text { area }\end{array}$} & \multicolumn{2}{|c|}{ Basal metabolism } & \multirow{2}{*}{$\begin{array}{l}\text { Basal } \\
\text { meta- } \\
\text { bolic } \\
\text { rate }\end{array}$} & \multirow{2}{*}{$\begin{array}{l}\text { Re- } \\
\text { spira- } \\
\text { tory } \\
\text { quo- } \\
\text { tient }\end{array}$} \\
\hline & & & & $\begin{array}{c}\text { Pre- } \\
\text { dicted }\end{array}$ & $\begin{array}{l}\text { Deter- } \\
\text { mined : }\end{array}$ & & \\
\hline December 8-15 & $\begin{array}{l}\text { Deliberate intake } \\
\text { of food greater } \\
\text { than desire }\end{array}$ & 62,610 & \begin{tabular}{|c}
$\begin{array}{c}\text { square } \\
\text { meters }\end{array}$ \\
1.79
\end{tabular} & $\begin{array}{c}\text { Calories } \\
1,679\end{array}$ & $\begin{array}{c}\text { Calories } \\
1,580\end{array}$ & $\begin{array}{l}\text { per cent } \\
-6.1\end{array}$ & .842 \\
\hline December $15-22$ & Same as above & 62,984 & 1.80 & 1,688 & 1,490 & -11.7 & .857 \\
\hline $\begin{array}{c}\text { December } 22- \\
\text { January } 13\end{array}$ & $\begin{array}{l}\text { Food according } \\
\text { to desire }\end{array}$ & 62,256 & 1.79 & 1,679 & 1,490 & -11.3 & .765 \\
\hline $\begin{array}{l}\text { January } 13- \\
\text { February } 13\end{array}$ & Same as above & 61,574 & & & & & \\
\hline $\begin{array}{c}\text { February 13- } \\
\text { March } 19\end{array}$ & Same as above & 60,943 & & & & & \\
\hline
\end{tabular}

diet. It is generally conceded that this phenomenon indicates that the disposal of the previously ingested food is still going on: in other words, that the metabolism has not yet fallen to its basal level because of the continued specific dynamic action.

In the third period when the subject was still over-eating, as evidenced by continued gain in weight, the basal metabolism quickly fell to its original level. This was to have been expected since the diet was now only moderately excessive and its specific dynamic action was complete before the determination of the basal metabolism on the following morning.

Here again there is no need of postulating a "Luxuskonsumption" to account for the facts.

Further information in regard to the response of the subject may be obtained from an analysis of the gain in weight during this period. The actual addition of body weight was 4,410 grams. It is conceivable that all of it might have been due to the retention of that amount of water. If this were true, it would necessarily also be true that he had burned all of the diet. However, an analysis of the data gives a quite 
different answer (7). The comparison between the available energy of the diet and the transformation of energy shows that the subject acquired 24,830 Calories deposited as 179 grams of protein and 2,499 grams of fat. These materials in the form of body tissue would deposit with them 787 grams of water. Hence, the addition of tissue amounted to 3,465 grams. In addition to this weight there should have been a water retention of 945 grams to account for the total gain in weight. The determination of the water exchange for the period accounted for the retention of 897 in addition to that deposited with the protein and fat. These considerations offer further evidence to demonstrate that the extra energy absorbed from the excessive diet was, in the main, stored and not burned.

\section{DISCUSSION}

About 20 years ago, Grafe stated that the oxidative rate in the animal organism was significantly affected by the amount of energy taken in. It had already been clearly demonstrated by several different investigators that the heat production in the basal state falls as much as 30 per cent due to prolonged starvation. Much later, F. G. Benedict (8) fed a group of men, who were habitually ingesting 3,200 to 3,600 Calories, a diet containing 1,400 Calories. After three weeks the average weight of the subjects had declined 12 per cent and their basal metabolism had fallen 18 per cent. They were now able to maintain this new low weight on 1,950 Calories, and the basal metabolism remained low. It is true then that the organism can reduce its rate of oxidation in response to underfeeding and, if the latter is not too extreme, weight may be maintained after an initial loss. This is clearly an adaptation capable of prolonging the life of the organism in the face of famine. On the other hand, it is not easy to picture any advantage obtainable through the ability to dispose of an over abundance of food rather than to store it so that it would be available in time of need.

Grafe, however, tried to prove that the normal mammalian organism did automatically dispose of excessive food through the mechanism of an increased metabolic rate. We have shown above that his data do not support his hypothesis, for when the fasting, resting metabolic rate of his dogs obtained during a period of over nutrition is compared with this rate obtained when the dog was apparently normal, no signifi- 
cant increase is found. He obtained an apparent increase by first pushing the rate down by means of a long period of starvation. He thus obtained a metabolic rate 26 per cent lower than the normal but, nevertheless, he accepted this value as a proper basis for comparison. The same criticism applies to the study of the patient whose rate was 22 per cent below normal when he was emaciated and in whom very marked "Luxuskonsumption" permitted the rate to return to the usual level for such an individual in health.

Even though the fasting, resting metabolism does not appear to be stimulated by previous over nutrition, it may still be true that the total transformation of energy can be increased by this factor, Grafe did not deal with this phase of the subject at all. However, due to the development of a method in this laboratory, such data are now obtainable without the use of a calorimeter.

The subject whom we studied belonged to the group of persons alleged to be pathologically lean because, accepting the dictum of Grafe, they oxidize all of the food taken into the body without regard to quantity. The slight increase observed in both the basal and total metabolism, on a super-maintenance diet, was found to be entirely attributable to the increase in surface area plus the extra specific dynamic effect of the greater diet. It was equally clear that this subject was quite capable of gaining weight when he took food in excess of his habitual desire. A scrutiny of his life brought out the important fact that he had always been indifferent in regard to food, and that he had consequently eaten sparingly. However, during a short period of his life he had food set before him which was so attractive that it overcame his indifference and he gained a large amount of weight during this interval. - A recognition of the fact that he habitually ate less than the usual amount of food for his group is sufficient reason for his thinness.

Clearly the body weight is affected on the one hand by the individual metabolic requirement and on the other hand by the total intake of energy. Evidently the mechanism, commonly called appetite, functions to maintain a balance between the supply and the demand. This is hardly the place to discuss the well known factors that influence appetite and individual metabolic requirements. Observations and special studies on appetite (9) in this clinic have convinced us that the 
abnormalities of body weight are regularly due to a failure of the appetite to make a complete adjustment between the inflow and outflow of energy.

\section{SUMMARY}

(1) The basal metabolism and the total transformation of energy of an unusually thin subject were recorded when (1) he was on a maintenance diet and (2) when he was being vigorously overfed.

(2) It could not be shown that either the basal or the total transformation of energy per square meter of body surface was increased by more than the increment due to the extra specific dynamic action of the additional food.

(3) On the other hand, the subject added about 4.5 kilograms to his weight in 15 days when he was being overfed.

(4) No support for the "Luxuskonsumption" hypothesis of Grafe was secured.

\section{BIBLIOGRAPHY}

1. Grafe, E., and Graham, D., Ztschr. f. physiol. Chem., 1911, 1xxiii, 1. Über die Anpassungsfähigkeit des tierischen Organismus an überreichliche Nahrungszufuhr.

2. Schöndorff, B., Arch. f. d. ges. Physiol., 1897, lxvii, 430. Ueber den Einfluss der Schilddrüse auf den Stoff wechsel.

3. Zuntz, N., Biochem. Ztschr., 1913, lv, 341. Einfluss chronischer Unterernährung auf den Stoff wechsel.

4. Grafe, E., and Koch, R., Deutsches Arch. f. klin. Med., 1912, cvi, 564. Über den Einfluss langdauernder, starker Überernährung auf die Intensität der Verbrennungen im menschlichen Organismus (Untersuchungen bei Mastkuren).

5. Newburgh, L. H., Wiley, F. H., and Lashmet, F. H., J. Clin. Invest., 1931, x, 703. A Method for the Determination of Heat Production Over Long Periods of Time.

6. Lusk, G., J. Nutrition, 1931, iii, 519. The Specific Dynamic Action.

7. Wiley, F. H., and Newburgh, L. H., J. Clin. Invest., 1931, x, 723. An Improved Method for the Determination of Water Balance.

8. Benedict, F. G., Miles, W. R., Roth, P., and Smith, H. M., Carnegie Inst. of Wash., 1917, Pub. No. 280. Human Vitality and Efficiency under Prolonged Restricted Diet.

9. Harrington, M. M., J. Am. Dietet. Assoc., 1930, vi, 101. Appetite in Relation to Weight. 